\title{
Flat surfaces machining by the magneto-abrasive method with permanent magnet end-type heads 2. The influence of the design of the working surfaces of the heads on the effectiveness of the magneto- abrasive machining
}

\author{
V.S. Maiboroda ${ }^{1} \bullet$ D. Yu Dzhulii ${ }^{1} \bullet$ A. I. Zelinko $\bullet$ A. O. Burikov ${ }^{1}$
}

Received: 23 September 2020 / Accepted: 24 November 2020

\begin{abstract}
Investigation of the magneto-abrasive machining process of flat surfaces of parts made of ferromagnetic material steel 45 by the end heads based on high-power permanent magnets, which form the magneto-abrasive tool of the "brush" type, was carried out. For ensuring the high efficiency of the magneto-abrasive machining process, an analysis of the machining by heads on the working surfaces of which located protrusions of various shapes, sizes and configurations was carried out. Twelve types of working surfaces were investigated. The control of magneto-abrasive machining process efficiency was curried for the changing of the parameter Ra, the value of the relative roughness and the rate of its change, the size of the surface's relative reference profile length from the section level of the formed microprofile and the parameter of geometric heredity obtained during the machining. It has been determined that the most rational design of the working surface of the end head with the magneto-abrasive tool of the "brush" type was the surface with 9-12 radial triangular protrusions located on it. Using of such heads provides a highly efficient form of the roughness of machined surfaces with $R a<0.03 \mu \mathrm{m}$ with an initial Ra of $0.8 \mu \mathrm{m}$ obtained after face milling. At the same time, microwaves had been formed after milling was almost eliminated. The kinetics formation of the relative reference profile length from the section level was analyzed by the nature of its size change. It was shown that at the initial stage, the predominant removal of micro peaks had occurred, and then micro valleys were actively machined with further smoothing of the microprofile.
\end{abstract}

Keywords: Magneto-abrasive machining, end-type magnetic heads, working surfaces, efficiency, roughness.

\section{Introduction}

Recently, considerable attention has been paid to the implementation of the method of magneto-abrasive machining (MAM) of parts of various shapes using heads with the high-power permanent magnet. This is due to the fact that such an approach to the method of magneto-abrasive machining does not require the creation of complex and bulky electromagnetic devices, and the heads themselves are quite mobile and without special restrictions can be used on standard metalworking equipment as a specialized movably coordinated abrasive tool.

D. Yu Dzhulii

dmytro.dzhulii@gmail.com

${ }^{1}$ National Technical University of Ukraine "Igor Sikorsky Kyiv Polytechnic Institute”, Kyiv, Ukraine

2 Society of manufacturing engineering and development Schmalkalden, Germany
In the scientific and technical literature, publications are widely presented about the calculation and forecasting of the capabilities of such devices [1,2], but without further analysis of the ways of their technical implementation in the process of real machining. The work [3] describes individual results obtained during the machining of the inner surfaces of carbide draw plates using cylindrical heads consisting of a set of ring magnets fixed on a rod made of paramagnetic material. The presented results indicate that this approach is promising for the implementation of the MAM method. The machining of flat surfaces of parts made of both ferromagnetic and paramagnetic materials is described in $[4,5]$. The real possibility of obtaining the surface with a roughness $R a<0.05 \mu \mathrm{m}$ after finish MAM was shown. However, the presented information is significantly limited both by the specific technological machining conditions and by the design features of the used heads. It should be noted that the data available in the scientific and technical literature related to the use of heads with the permanent magnet in the technological process were obtained with a sufficiently long technological machining time - 5- 
10 minutes or more. Which is not entirely consistent with most works in the field of MAM, where the rational machining time does not exceed $60-240$ s [6-9].

It was previously established that to ensure the effective MAM process, three conditions must be met [10]. Under these conditions, depending on the machining tasks being set, the possibility of achieving the corresponding values of the normal $-V n$ and tangential $-V \tau$ components of the speed of the relative movement of particles of the magneto-abrasive tool (MAT) and a surface of the part. If the first of the tasks of creating the necessary conditions for pressing the particles of the magnetic abrasive to the machined surface is largely determined by the characteristics of permanent magnets, that are used in the magnetic heads and the conditions for the concentration of the magnetic field in the working gap, then to obtain the necessary speeds of relative movement of the MAT particles and the surface of the part, it is reasonable using of special designs of magnetic heads. Special structural elements of magnetic heads, made on their working surfaces, should have an additional effect on the portions of magneto-abrasive powder (MAP) in the working gaps, ensuring the fulfillment of the conditions under which the speed of movement of MAP particles along the working surfaces of the head will be minimal, but sufficient for mixing powder during the entire machining cycle, and the speed of movement of particles relative to the machined surface will be minimally different from the speed of the main working movement of the head - rotation around its axis. One of the ways to fulfill these conditions can be using protrusions of various shapes and configurations, made on the working surface of the end magnetic heads. The choice of the rational protrusion's shape, size and nature of their location on the working surface of the heads is undoubtedly an urgent task. Previously carried out preliminary experimental studies $[11,12]$ made it possible to determine the direction of further work.

The goal of the work was to determine the most rational design of the working surface of the end-type magnetic heads, the use of which in the machining of ferromagnetic parts will ensure an effective process of finish MAM.

\section{Experimental researches}

For MAM of flat surfaces, that were obtained after face milling by cutters with a working diameter of $250 \mathrm{~mm}$, with $R a=0.8 \mu \mathrm{m}$ on samples made of steel 45 were used end heads in the shape of a "brush" made of high-power neodymium magnets in the form of a cylinder with $40 \mathrm{~mm}$ in diameter and $20 \mathrm{~mm}$ high located in a diamagnetic mandrel [11]. The machining was carried out with Ferromap powder with the particle size of $630 / 400 \mu \mathrm{m}$, which has proven itself in previous studies, at the head rotation frequency of $900 \mathrm{rpm}$, the working gap of $3 \mathrm{~mm}$, and the variable feed rate in the range of $10-35 \mathrm{~mm} / \mathrm{min}$. To assess the effectiveness of the MAM process were analyzed the nature of the change in the value of the parameter $R a$ and its relative change

$$
\Delta R a=\left(R_{\text {initial }}-R_{\text {final }}\right) / R_{\text {initial }}
$$

where $R_{\text {initial }}$ is the value of the Ra parameter before MAM, after milling and $R_{\text {final }}$ is the value of the Ra parameter after MAM. The specified parameters were determined both along and across the direction of face milling. In order to assess the features of the change in roughness along $R a^{\text {along }}$ and across $-R a^{\text {across }}$ the direction of face milling, were analyzed the value that makes it possible to roughly estimate the anisotropy of the change in the parameter $R a$ on the machined surfaces

$$
A(R a)=R a^{\text {along }}-R a^{\text {across }},
$$

i.e. by the value of $A(R a)$ can be, to a certain extent, assessed the decrease in the value of geometric heredity from the previous machining.

For the creation of the various shaped protrusions and configurations on the working surfaces of the end heads, special replaceable cylindrical attachments with a diameter of $50 \mathrm{~mm}$ were used, that were made of highstrength plastic on a 3D printer. These attachments were mounted on the working surface of the head. The appearances of the investigated types of attachments with protrusions on the working parts are presented in table 1 . The height of the protrusions above the flat working surface was $2 \mathrm{~mm}$.

The nature of the change in the value of the relative roughness $\triangle R a$ after MAM with heads with various attachments and directly the value of the parameter $R a$ both along $R a^{\text {along }}$ and across the direction of milling before MAM $R a^{\text {across }}$ are presented in table 2 .

The analysis of the carried out studies showed that the obtained dependences of the change in the value of the relative roughness $\Delta R a$ on the cross-feed rate of the working head without a significant loss in accuracy can be described in the above ranges by linear functions of the form:

$$
\Delta R a=k_{V} \cdot s
$$

where $s$ is the speed of the cross-feed of the head, $k_{V}$ is the proportionality coefficient, which shows the rate of change of the parameter $\Delta R a$ depending on the feed of the working head during MAM.

It was defined that the change in the $k_{V}$ value with an increase in the feed rate of the head or, in other words, with a decrease in the contact time of the working surfaces of the heads, on which the MAT is formed, with the machined surfaces has the negative character. The calculated $k_{V}$ values for the studied types of heads with attachments are presented in table 3 . The carried out the simultaneous analysis of the change in the roughness value from the feed rate showed that the smallest roughness after MAM with various heads $R a<0.1 \mu \mathrm{m}$ is formed at the feed rate of 10 and $15 \mathrm{~mm} / \mathrm{min}$. 
Table 1. Types of working surfaces of cylindrical attachments on the magnetic end heads

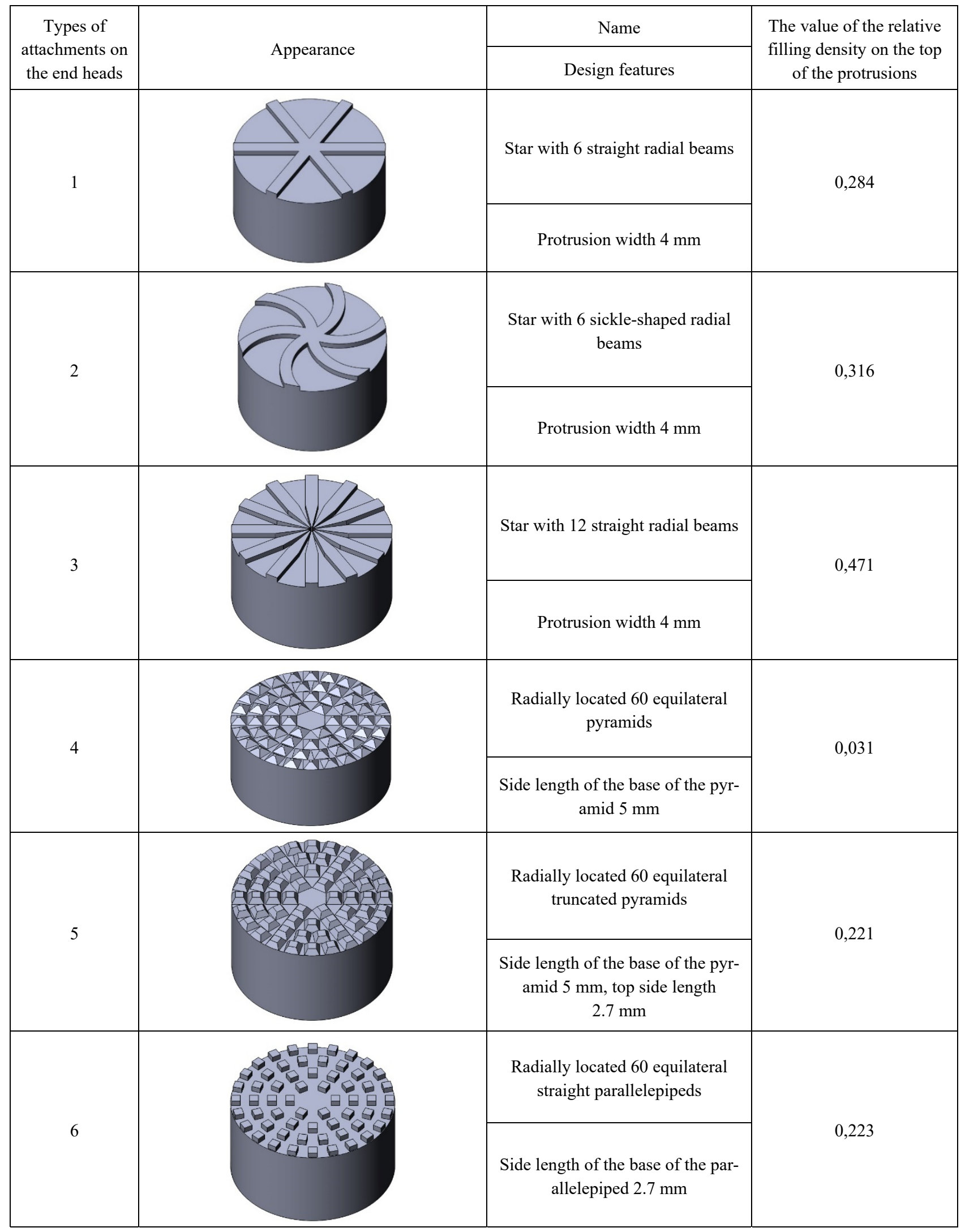


Table continuation

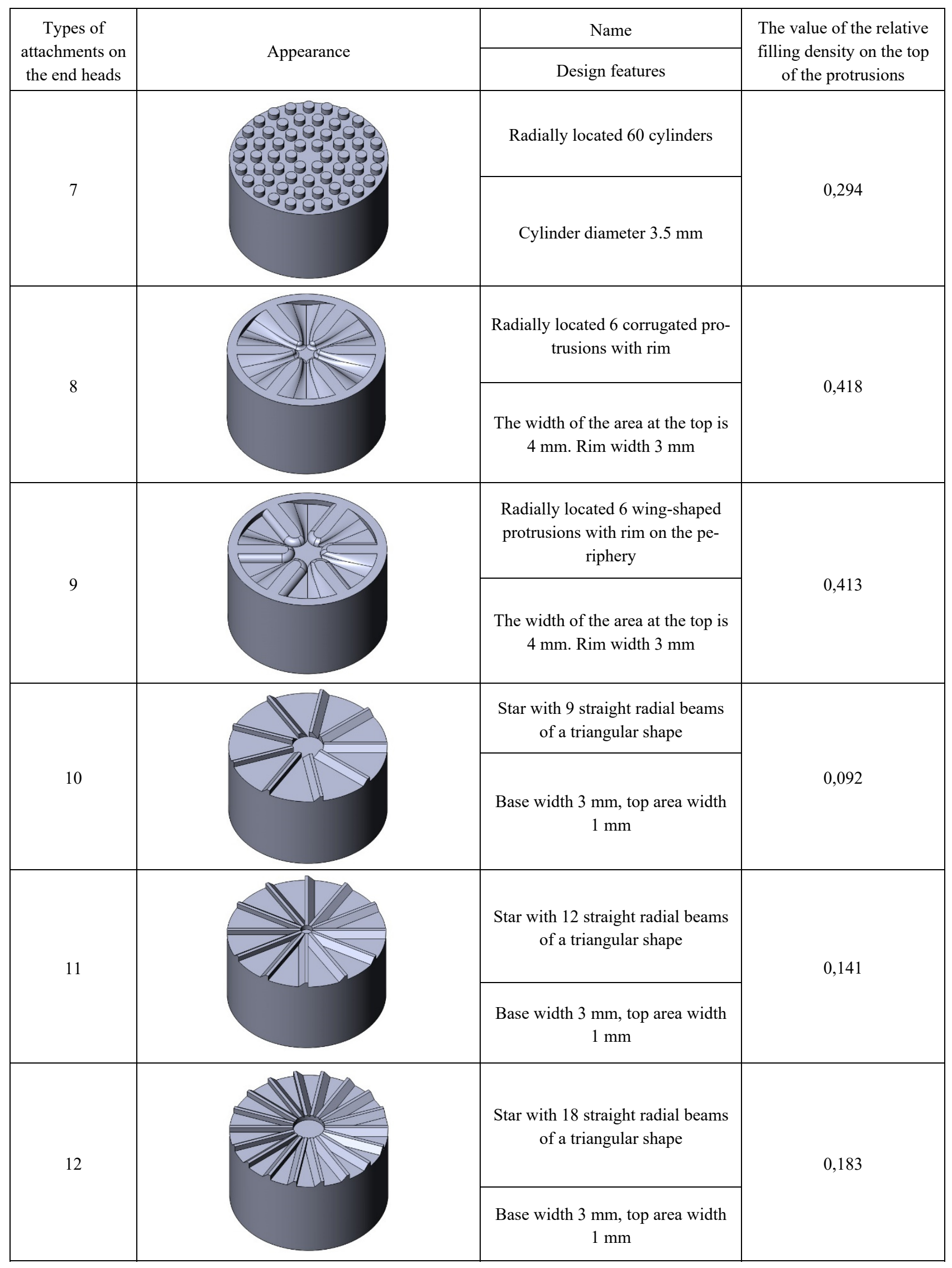


Table 2. Changes in $\triangle R a$ and $R a$ values after MAM by different heads

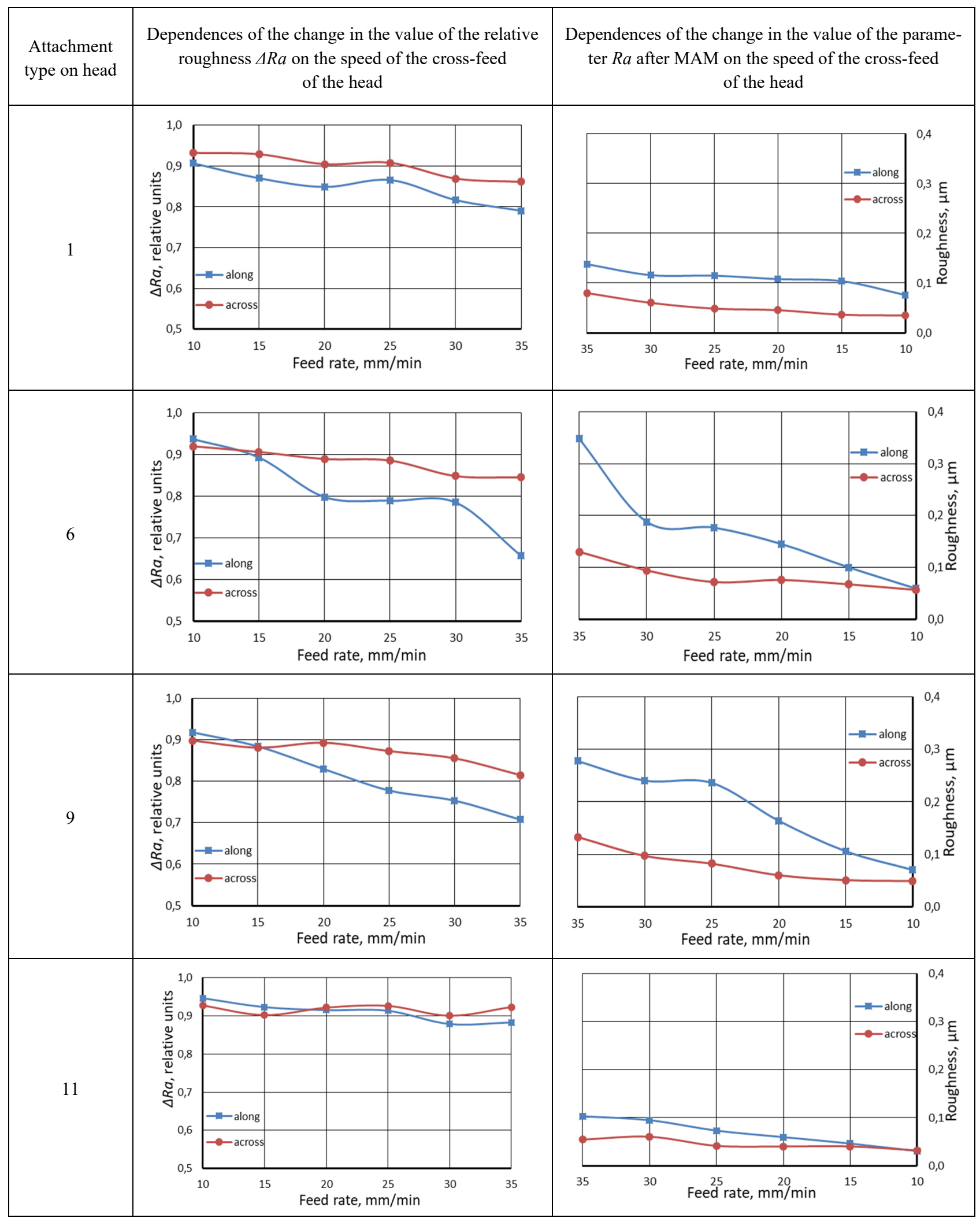


Table 3. $k_{V}$ values for different types of heads

\begin{tabular}{|c|c|c|c|c|c|c|c|c|c|c|c|c|c|}
\hline \multicolumn{2}{|c|}{$\begin{array}{c}\text { Attachment type } \\
\text { on head }\end{array}$} & 1 & 2 & 3 & 4 & 5 & 6 & 7 & 8 & 9 & 10 & 11 & 12 \\
\hline \multirow{2}{*}{$\begin{array}{l}k_{V} \text { value } \\
\mathrm{min} / \mathrm{mm}\end{array}$} & along & $-0,0054$ & $-0,0123$ & $-0,012$ & $-0,0058$ & $-0,0096$ & $-0,0092$ & $-0,0119$ & $-0,0163$ & $-0,0085$ & $-0,005$ & $-0,0033$ & $-0,0076$ \\
\cline { 2 - 13 } & across & $-0,0037$ & $-0,0071$ & $-0,0102$ & $-0,0047$ & $-0,0056$ & $-0,0042$ & $-0,0077$ & $-0,0094$ & $-0,0044$ & $-0,0028$ & $-0,0019$ & $-0,0041$ \\
\hline
\end{tabular}

The best results - the smallest roughness was ensured when using attachments on heads №1, №4, №10, №11 and №12. Common to these heads is the low value of the relative filling density on the tops of the protrusions. It should be noted that the attachment with six radial beams - №1 falls out of this trend. The number of radially located protrusions plays a positive role. It was shown that the presence of $6-18$ radially located protrusions made it possible to achieve the parameter $R a<0.15 \mu \mathrm{m}$ even at the feed rate of $35 \mathrm{~mm} / \mathrm{min}$. This, to all appearances, occurs due to the peculiarities of the formation of the MAT at the end of the heads, when the radial protrusions provide the conditions under which the speed of movement of particles relative to the machined surface is minimally different from the speed of the main working movement of the head - rotation around its axis and at the same time the continuity of the contact of the MAT with the machined surface does not disturb. Also, to all appearances, a stably and quasi-stable zone of compacted magneto-abrasive powder is formed in front of each protrusion - a locking zone, which contributes to an increase in the machining efficiency. Confirmation of the formation of the relatively stable locking zone can be the results, which were obtained on attachments with different shapes of protrusions when only pyramidal protrusions provide relatively high machining performance at a low filling density on the tops of the protrusions. However, at the same time the protrusions relatively stable hold compacted portions of magneto-abrasive powder in the quasistable state, which form locking zones. Also, to all appearances, a stably and quasi-stable zone of compacted magneto-abrasive powder is formed in front of each protrusion a locking zone, which contributes to an increase in the machining efficiency. Confirmation of the formation of the relatively stable locking zone can be the results obtained on attachments with different shapes of protrusions when only pyramidal protrusions provide relatively high machining performance at a low filling density on the tops of the protrusions, but at the same time relatively stably hold compacted portions in a quasi-stable state magneto-abrasive powder, which form locking zones. It should be mentioned the results on the change in the parameters of the microprofile of the workpiece's surface after MAM by the head with attachment №2 - the star with 6 sickle-shaped radial beams. The results obtained are significantly worse than at machining by the head with straight beams - №1, which is associated with the peculiarities of the movement of the magneto-abrasive powder in the machining zones and requires additional research associated with different configuration and sizes of radially located protrusions.

At the next stage of the analysis of the obtained results, will be considered the data obtained on the heads that provide the lowest roughness and the highest intensity of its achievement at MAM. The estimation of the anisotropy of the change in the parameter $R a$ on the machined surfaces by the change in the value of $A(R a)$ was carried out, which makes it possible to estimate the decrease in the value of geometric heredity from the previous machining - face milling.

The obtained results of calculations are presented in the form of dependencies of the change in the value $A(R a)$ on the feed rate at MAM in Fig. 1. It was shown that the best results in reducing the value of geometric heredity from the previous machining were obtained for head №11 - the star with 12 straight radial beams of a triangular shape. Quite good results were obtained for head №10 with 9 straight radial beams of a triangular shape, especially at low feed rates $-10-20 \mathrm{~mm} / \mathrm{min}$, when the process of dead-stop grinding of the machined surface is realized, and the machining time for each elementary section of the workpiece surface was $2-4 \mathrm{~min}$.

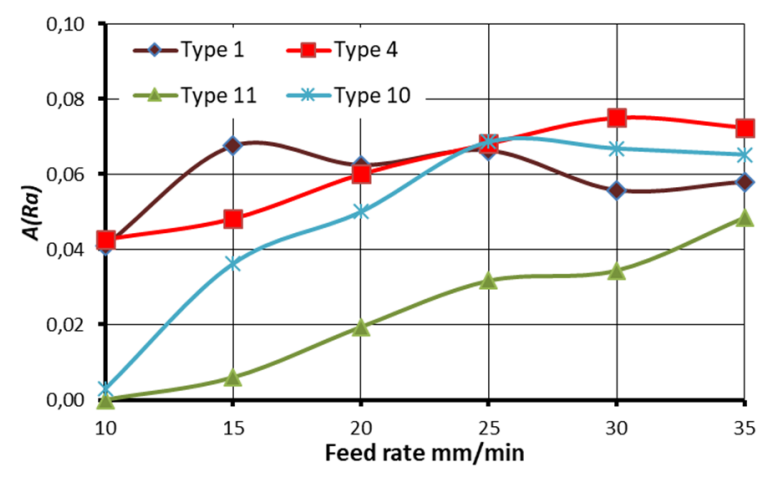

Fig. 1. Dependences of the change in the $A(R a)$ value on the feed rate with MAM by heads of various types

Removal of the results of geometric heredity - microwaves, which were obtained during milling, is confirmed by surface profilograms (Fig. 2).

The increased efficiency of MAM by the above heads with attachments №1, №4, №10, №11 and №12 is also confirmed by the values of the surface roughness after machining at the feed rate of $35 \mathrm{~mm} / \mathrm{min}$, which does not 

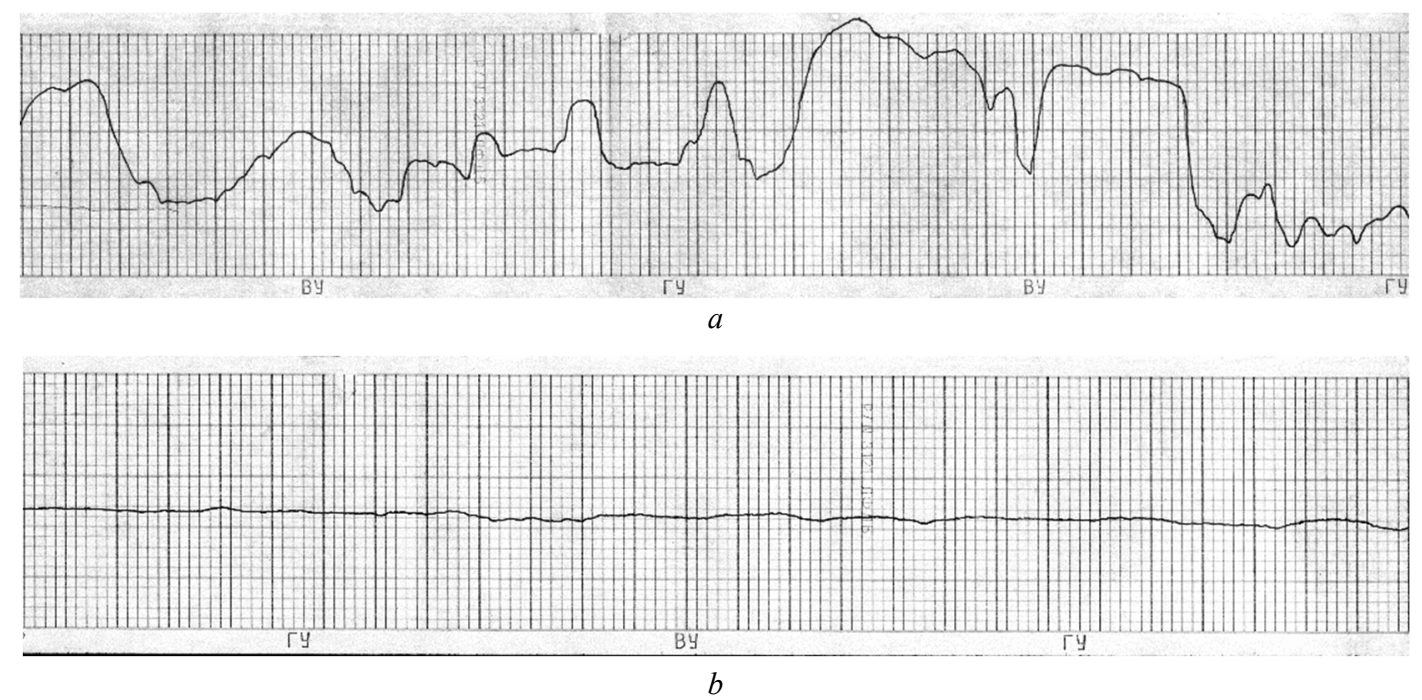

Fig. 2. Profilograms of the workpiece surface $a$ ) - after milling and $b$ ) - after MAM by the head with the attachment №11 and the feed rate of $15 \mathrm{~mm} / \mathrm{min}$, horizontal magnification 500, vertical magnification 100000

exceed the $R a$ value of $0.18 \mu \mathrm{m}$ and by the smallest values of the decrease rate of the parameter $\Delta R a-k_{V}$ depending on the feed of the working head.

Let us analyze the kinetics of the formation of the surface micro-profile by the nature of the change in the support surface depending on the feed rate. The change of the $t p$ from the profile section level is shown in Fig. 3.

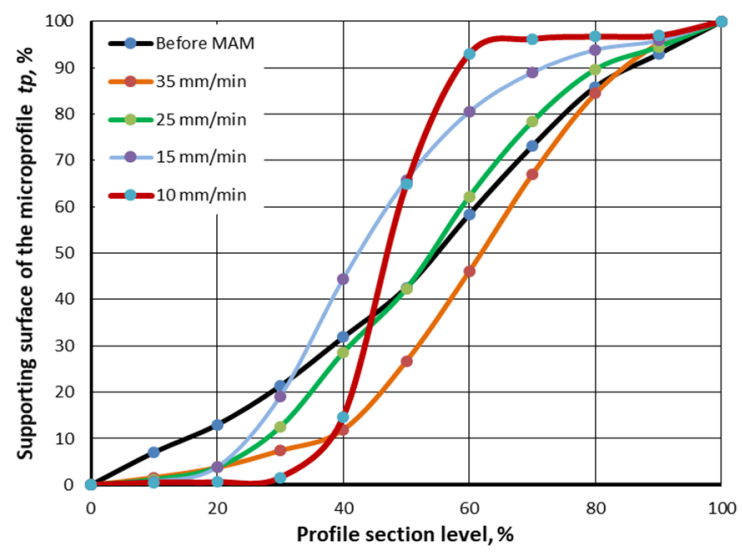

Fig. 3. Change of the size of the supporting surface of the microprofile from the profile section level after MAM by the end head No.11 at different feed rates $-s$

It was shown that at the head feed rate of $35 \mathrm{~mm} / \mathrm{min}-$ the shortest time of MAT contact with each section of the machined surface, the predominant removal of the tops of microroughness of the milled surface occurs. In this case, an average roughness with $R a=0.1 \mu \mathrm{m}$ is formed. The decrease in the feed rate to $25 \mathrm{~mm} / \mathrm{min}$ provides the decrease in the $R a$ value to $0.07 \mu \mathrm{m}$. With the indicated feed - respectively longer time of contact of the MAT with the surface, more uniform machining of micro peaks and micro valleys is realized. The increase in the contact time of the MAT with the machined surface, which occurs when the head feeds equal 15 and $10 \mathrm{~mm} / \mathrm{min}$, leads to the uniform removal of micro peaks and the polishing of micro valleys with almost complete elimination of waviness obtained after face milling. That is, as noted above, occurs process similar to sparking-out during grinding. In this case, the roughness with $R a<(0.03-0.035) \mu \mathrm{m}$ is formed. This is confirmed by tridimensional images of the surface profile after milling and after MAM at the feed rate of $10 \mathrm{~mm} / \mathrm{min}$ (Fig. 4) on the square area with a side of $2 \mathrm{~mm}$, obtained with the NanoFocus microscope.

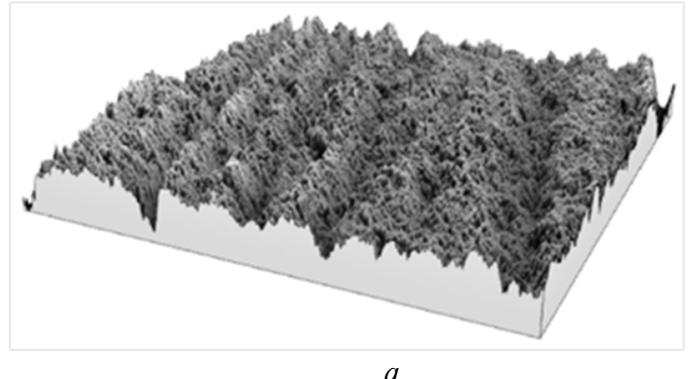

$a$

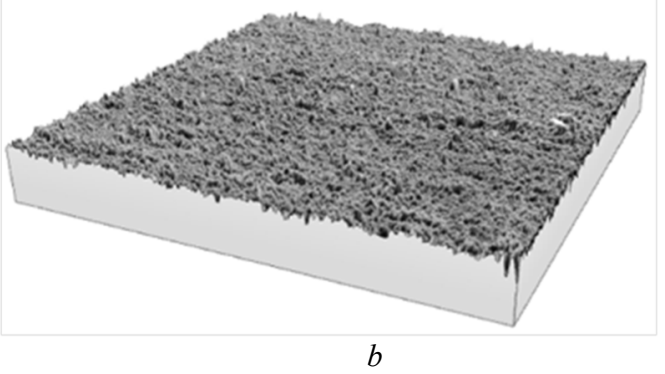

Fig. 4. 3D images of the surface microprofile after milling with the face mill $-(a)$ and after the technological cycle milling + MAM with the end head $-(b)$ 


\section{Conclusions}

In the work was carried out the study of the process of magneto-abrasive machining of flat surfaces of parts made of ferromagnetic material steel 45 by the end heads based on high-power permanent magnets, which form the magneto-abrasive tool of the "brush" type. For the formation of a magneto-abrasive brush with the rational shape, which makes it possible to ensure high efficiency of the MAM process, the analysis of the machining by heads on the working surfaces of which located protrusions of various shapes, sizes and configurations was carried out. Twelve types of working surfaces were investigated. The control of MAM process efficiency was curried for the changing of the parameter $R a$, the value of the relative roughness and the rate of its change, the size of the surface's relative reference profile length from the section level of the formed microprofile and the parameter of geometric heredity obtained during the machining. It has been determined that the most rational design of the working surface of the end head with the MAT of the "brush" type was the surface with $9-12$ radial triangular protrusions located on it. Using of such heads allows the highly efficient formation of the roughness of machined surfaces with $R a<0.03 \mu \mathrm{m}$ with an initial $R a$ on the level $0.8 \mu \mathrm{m}$ obtained after face milling by mills with the working diameter of $250 \mathrm{~mm}$. At the same time, microwaves had been formed after milling was almost eliminated. The kinetics formation of the relative reference profile length from the section level was analyzed by the nature of its size change. It was shown that at the initial stage, the predominant removal of micro peaks had occurred, and then micro valleys were actively machined with further smoothing of the microprofile.

\section{References}

[1] S.L. Leonov, A.M. Ikonnikov and R.V Grebenkov, "Calculation of magnetic induction in the working gap during magnetoabrasive machining of flat surfaces of workpieces made of ferromagnetic and non-magnetic materials with permanent magnet inductors", Technological Equipment, Machining Attachments and Instruments, vol. 4, pp. 49-54, 2017. doi: 10.4028/www.scientific.net/amm.788.69

[2] A.M. Ikonnikov et al., "Analysis of magnetic forces in the working clearance with magnetic-abrasive treatment of inductors on standing magnets”, Journal of Modern Technologies, vol. 3(11), pp. 27-32. 2018.

[3] V.V. Gusev, S.V. Kucherenko and K.S. Sukhoruchko, "Magnetic-abrasive machining of internal surfaces with use of permanent magnets", Scientific works of DonNTU, vol. 8, pp. 145-151, 2011.

[4] K. Harsh and G.Vishwas, "Magnetorheological nano-finishing of diamagnetic material using permanent magnets tool", Precision Engineering, vol. 51, pp. 30-39, 2018. doi: 10.1016/j.precisioneng.2017.07.003

[5] Ya. Zou et al., "Study on complex micro surface finishing of alumina ceramic by the magnetic abrasive finishing process using alternating magnetic field”, The International Journal of Advanced Manufacturing Technology, vol. 97, pp. 2193-2202, 2018. doi: https://doi.org/10.1007/s00170-018-2064-0

[6] Yu.M. Baron, Magnitno-abrazivnaya i magnitnaya obrabotka izdelii i rezhushchikh instrumentov [Magneto-abrasive and magnetic machining of products and cutting tools], Leningrad, Russia: Mashinostroenie, Baron, 1986.

[7] B.E. Oliker, Poroshki dlya magnitno-abrazivnoi obrabotki i iznosostoikikh pokrytii [Powders for magneto-abrasive machining and wear resistant coatings], Moscow, Russia: Metallurgy, 1990.

[8] S.A. Klimenko et al., Finishnaya obrabotka poverkhnostei pri proizvodstve detalei [Surfaces finishing in the manufacturing of parts], S.A. Chizhik, M.L. Kheifets eds. Minsk, Belarus: Belaruskaya navuka, 2017.

[9] F.Yu. Sakulevich, Osnovy magnitno-abrazivnoi obrabotki [Fundamentals of Magneto-abrasive machining], Minsk, Belarus: Nauka i tekhnika, 1981.

[10] V.S. Maiboroda, "Investigation of the properties of a magneto-abrasive tool formed from two fractional mixtures of powders during magneto-abrasive machining in large magnetic gaps", Technological systems, vol. 1(37), pp. 40-55, 2007.

[11] V.S. Maiboroda et al., "AISI 1045 steel flat surfaces machining using the magneto-abrasive method", Journal of Engineering Sciences, vol. 7(1), pp. A1-A7, 2020. doi: 10.21272/jes.2020.7(1)

[12] V.S. Maiboroda et al., "Magneto-abrasive machining of flat surfaces with permanent magnet heads", Technical Engineering, vol. 1(85), pp. 60-65, 2020. https://doi.org/10.26642/ten-2020-1(85)-60-65 


\title{
Обработка плоских поверхностей магнитно-абразивным методом торце- выми головками на постоянных магнитах \\ 2. Влияние конструкции рабочих поверхностей головок на эффективность магнитно-абразивной обработки
}

\author{
В. С. Майборода, Д. Ю. Джулий, А. И. Зелинко, А. О. Буриков
}

Аннотация. Выполнены исследования процесса магнитно-абразивной обработки плоских поверхностей деталей из ферромагнитного материала сталь 45 ториевыми головками на базе высокомощных постоянных магнитов, формирующих магнитно-абразивный инструмент типа «щетка». Для обеспечения высокой эффективности прочесса магнитно-абразивной обработки выполнено анализ обработки головками на рабочих поверхностях которых выполнены выступы разной формы, размеров и конфигурации. Исследовано двенадиать типов рабочих поверхностей. Контроль эффективности процесса магнитно-абразивной обработки выполняли по изменению параметра Ra, величины относительной шероховатости и скорости ее изменения, величины опорной поверхности формируемого микропрофиля и параметра геометрической наследственности, полученной при обработке. Установлено, что наиболее рациональной конструкцией рабочей поверхности ториевой головки с магнитно-абразивным инструментом типа «щетка» будет поверхность, с нанесенными на нее 9 - 12 лучеобразными выступами треугольной формы. Использование таких головок обеспечивает высокоэффективное формирование шероховатости обработанных поверхностей с Ra $<0,03$ мкм при исходной Ra на уровне 0,8 мкм, полученной после ториевого фррезерования. При этом практически полностью устраняется микроволнистость, формирующаяся при фррезеровании. По характеру изменения величины относительной опорной поверхности микропрофиля проанализирована кинетика его формирования. Показано, что на начальном этапе происходит преимущественное удаление микровыступов, в последующем активно обрабатываются микровпадины с дальнейшим выглаживанием микропрофиля

Ключевые слова: магнитно-абразивная обработка, магнитные головки ториевого типа, рабочие поверхности, эффективность, шероховатость.

\section{Оброблення плоских поверхонь магнітно-абразивним методом торцевими головками на постійних магнітах}

\section{2. Вплив конструкції робочих поверхонь головок на ефективність маг- нітно-абразивного оброблення}

\begin{abstract}
Майборода Віктор Станіславович, Джулій Дмитро Юрійович, Зелінко Андрій Ігорович, Буріков Олексій Олегович
Анотація. Виконано дослідження прочесу магнітно-абразивного оброблення плоских поверхонь деталей з феромагнітного матеріалу сталь 45 ториевими головками на базі високопотужних постійних магнітів, які формують магнітно-абразивний інструмент типу «щітка». Для забезпечення високої ефективності процесу магнітно-абразивного оброблення виконано аналіз оброблення головками на робочих поверхнях яких виконані виступи різної форми, розмірів і конфігурації. Досліджено дванадиять типів робочих поверхонь. Контроль ефективності процесу магнітно-абразивного оброблення виконували за зміною параметра Ra, величини відносної шорсткості і швидкості ї̈ зміни, величини опорної поверхні формуючогося мікропрофілю та параметра геометричної спадковості, отриманої при обробленні. Встановлено, що найбільш рачіональною конструкцією робочої поверхні ториевої головки з магнітно-абразивним інструментом типу «щітка» буде поверхня, з нанесеними на неї 9 - 12 променеподібними виступами трикутної форми. Використання таких головок забезпечує високоефективне формування шорсткості оброблених поверхонь з Ra <0,03 мкм при початковій Ra на рівні 0,8 мкм, отриманій після ториевого фрезерування. При иьому практично повністю усувається мікрохвилястість, що формується при фрезеруванні. За характером зміни величини відносної опорної поверхні мікропрофілю проаналізована кінетика його формування. Показано, що на початковому етапі відбувається переважне видалення мікровиступів, в подальшому активно обробляються мікровпадини з подальшим вигладжуванням мікропрофілю.
\end{abstract}

Ключевые слова: магнітно-абразивне оброблення, магнітні головки ториевого типу, робочі поверхні, ефективність, шорсткість. 